\title{
THE MANAGEMENT OF CHANGE AT SELECTED HIGHER EDUCATION INSTITUTIONS: AN EXPLORATION OF THE CRITICAL INGREDIENTS FOR EFFECTIVE CHANGE MANAGEMENT
}

\author{
P GOVENDER \\ School of Human Resource Management \\ University of KwaZulu Natal (Westville campus) \\ S MOODLEY \\ School of Governance \\ University of KwaZulu Natal (Westville campus) \\ $S$ BRIJBALL PARUMASUR \\ School of Human Resource Management \\ University of KwaZulu Natal (Westville campus)
}

\begin{abstract}
The study investigates management's perception of the change management process in terms of the impact of communication, behaviour, feelings and knowledge of staff and management, staff participation in the change process and overall attitude of staff. The perceived impact of the new situation and perceived acceptance and understanding of the change process were assessed. The subjects comprised of Management Committee (Manco), Deans and Directors of administrative sections from three tertiary institutions in KwaZulu-Natal. Data was collected using questionnaires, which were analysed using descriptive and inferential statistics. The results shed light on the critical ingredients for effective change management.
\end{abstract}

\section{OPSOMMING}

Die onderhawige studie ondersoek bestuur se persepsie van die veranderingsbestuursproses in terme van die impak op kommunikasie, gedrag, gevoelens en kennis van personeel en bestuur, personeeldeelname in die veranderingsproses en oorkoepelende houdings van die personeel. Die waargenome impak van die nuwe konteks en waargenome aanvaarding en begrip van die veranderingsproses is beoordeel. Die deelnemers het bestaan uit die bestuurskomitee, dekane en direkteure van administratiewe afdelings van drie tersiêre instellings in KwaZulu-Natal. Die data is met behulp van vraelyste ingesamel wat deur middel van beskrywende en inferensiële statistiesemetodes ontleed is. Die resultate werp lig op die kritieke bestanddele vir doeltreffende veranderingsbestuur.

The historical elections of 1994 created immense changes in stabilising South Africa in the political, economic, social and educational environment. This emergence and the national plan for higher education compelled the educational sector to change, reposition itself and make alterations to the fundamental areas of its structure and operations. Hence, the co-operative links of society, deregulation, the pressures of politics and government, and global changes made a compelling demand on the educational sector to change. Education has a remarkable potential to achieve the economic and social expectations of society (Varghese, 2004). The higher education agenda is far broader than ever before, placing greater responsibilities and choices on the leaders in this arena (Newby, 2003). The emphasis is on higher education's crucial role in terms of the knowledge and information it brings in promoting social progress and values.

South Africa's labour force is the essential resource for the progression and upliftment of the economy, and higher education's contributory role is required to provide the necessary skills. The mutual dependence between higher education and the economy, and between higher education and government has created a different kind of parallel, the focus of which lies in social needs, in boosting the economy, and being able to position itself in the global marketplace. Hence, the country has to pace itself accordingly. Similarly, politics influence the economic and social spheres of society, impacting on the economy, job creation and education. The transformation of the higher education system has been shaped by political changes. Sociopolitical change can be anticipated

Requests for copies should be addressed to: P Govender, School of Human Resource Management, University of Kwa-Zulu Natal (Westville Campus), Private Bag X54001, Durban, 4000 by observing internal pressures and then creating suitable organisational responses. According to the Green Paper on Higher Education Transformation (1996), higher education will have to generate the skills and technological advancements necessary for successful economic participation in the global market. It is clear that the redirection of the area of focus for higher education is towards solving socio-political and economic problems.

The provision of skills development by tertiary educational institutions makes graduates the country's assets since they substantially contribute to the escalation of economic growth. Hence, institutions are needed to negotiate market forces successfully in order to address the country's resource needs while preserving and building on core principles (New Directions for Student Services, 2000). The implication is that we need to build and sustain academic environments that will prepare educated citizens who will contribute effectively to the needs of the economy and society. Thus, education is an important source of the productivity of labour, impacting on the economy and making higher education more responsive to market needs, while simultaneously providing for the workforce and keeping pace with its goals. Such an alignment of institutional and societal values will stimulate the educational environment and therefore, enhance the intellectual pursuits of people.

\section{Change in Higher Education}

The present focus in the educational arena at national and institutional levels is change, transformation and transition. The aim is cost effectiveness and is often achieved through mergers and restructuring which may entail rationalisation. The concept 'change' is global and unavoidable. Seijts and O'Farrell 
(2003) state that change involves risk and requires the creation of new systems. Massive change is impacting on all facets of society, creating new dimensions and great uncertainty and, the issues facing us today is how to manage such change (Bowin, 2001). The momentum of change has an impact on structures and operations within tertiary educational institutions. This requires effective managerial leadership and governance of tertiary institutions. With relevant role competencies, drive, motivation, enthusiasm and people management skills amongst other salient competencies, tertiary change managers can oversee the change process with optimism. The notion of predicting the traditional ways of doing things is non-existent. Change re-energises the system, promotes growth and creates challenges for people. Fox, Schwella and Wissink (1991) submit that change is not limited to modifying organisational processes. Hence, besides facing the usual perennial matters of quality, accountability and cost effectiveness, tertiary change managers are required to seek new solutions to growing demands in a multicultural environment. These include reexamining and altering essential aspects of its structure and operations, whilst facing complexities and challenges. Therefore, the change process needs strong leadership support. A salient point of Seijts and O'Farrell (2003: 3) is that leadership "includes establishing a new direction for the organization, inspiring people to change their behaviors and routines consistent with the new direction, and coaching them on how to overcome barriers to change". Hence, in addition to management skills, coaching and guiding behaviours are of primary importance in major transformation processes (Eisenbach, Watson and Pillai, 1999).

Change management also comprises efforts to alter the behaviour of individuals (to reduce fears or stereotypes), to increase their confidence in themselves and to make them more open, co-operative and trusting. Tertiary change managers need to take cognizance of the existence of staff resistance to change. Unavoidable changes in tertiary institutions affected staff in numerous ways. With the merger of tertiary educational institutions, the following were evidenced: poor staff morale, staff insecurities due to possible retrenchments, redundancies and redeployment (Seijts and Farrell, 2003). Seijts and Farrell (2003: 2) assert that "Unless the need to change is perceived as an effort to create positive outcomes including, but not limited to, the expansion of personal power and a more interesting job, individuals can be expected to resist the initiatives that are part of the overall change effort". According to Hammond (1999: $35)$, “... it is simply not sustainable to ignore people's development needs. Giving employees the potential for personal growth is, in the long-term, the only real alternative to job security. Employers who do not pay attention to the development needs of their staff will only lose people faster". Chang (1994: 90) submits the importance of realizing that "attitudes are both cognitive and highly emotional - our minds form the attitudes, and we often react to them on a gut level". Attitudes in a work environment reflect people's feelings towards their work. An attitude is the way one thinks, feels and acts toward some aspect of the environment. The respective cognitive, affective, and behavioural aspects determine attitudes (Dailey, Keenan and Tayeb, 1994). In addition, Gibson, Ivancevich and Donnelly (1994) maintain that a person's cognitive style is established by both perception and judgement. In a work environment, behaviour is linked to the functions that people perform. New roles force individuals to adopt new attitudes and behaviours. The indication is that behaviour and attitude cannot be discussed in isolation. The implication is that by nurturing positive attitudes with staff, the goals of change management can be accomplished.

According to Van Tonder (2004: 189), "The pivotal role of management in change has been articulated from many different perspectives. It is obvious that the manager is the primary interface or buffer between environmental change that necessitates adaptation by the organisation, and the organisation's employees, who have to be redirected in terms of their focus, output and responsibilities as part of an internal change effort". In addition, throughout the change process, managers need to, inter alia, outline goals, evaluate current situations, assess salient features of end results of change and investigate what is required in order to change. Smit and Cronje, cited in Van der Waldt \& Knipe (1998: 30), reflect that the change management process can be sub-divided as follows: "Awareness of the forces for change, recognition of the need for change; diagnosis of the problem; identification of alternatives for the development of the organization; recognition of the restricting circumstances; selection of a method for change; and implementation and monitoring change strategies". In the context of a tertiary educational environment, the change management process is an organised and planned approach, incorporating strategy, structure and training, amongst other aspects aimed at organisation renewal. Therefore, a well structured change management process may facilitate change. Outstanding qualities such as transformational, charismatic and visionary leadership which thrive on organisational transformation are of relevance to organisations where dynamic changes are planned. Reflections on the positive aspects of change is beneficial when viewing the long-term goals of the institution. The deduction is that although change managers are faced with a major initiative involving complexities, their vision, drive, role competencies, and resources, can enable a smooth transition.

\section{Objectives of the study}

- To assess the perceptions of the Executive Management (Manco, Deans, Directors) of the change management process in terms of communication, staff attitudes and participation in the process.

- To evaluate the perceptions of the Executive Management of how the changed situation will impact on the efficiency and effectiveness of the institution in the short and long terms.

- To understand how the relevant constituencies (staff, students, management) understood and accepted the change process.

- To develop a model/framework that will identify the critical factors and present recommendations that will contribute to effectively managing change in education.

\section{Hypotheses}

Hypothesis 1

The opinions of Executive Management (Manco, Deans, Directors) regarding the impact of communication, behaviour, feelings, knowledge, participation and overall attitude on change management respectively, significantly relate to each other.

\section{Hypothesis 2}

There is a significant correlation between the perceptions of Manco and Directors regarding the impact of the new situation on their effectiveness and efficiency in the short-term and long-term.

\section{Hypothesis 3}

There is a significant correlation between the perceptions of Deans regarding how the change process was accepted and understood by the relevant constituencies (staff, students) at the various institutions.

\section{METHOD}

\section{Research design}

The research methodology has been designed to determine staff behaviour and attitude and its impact on change management, incorporating relevant aspects of the change process pertinent to tertiary educational institutions. The use of both quantitative and qualitative data provides a balanced evaluation of the findings of the study. 


\section{Sample}

The population comprised of all decision-makers involved in managing the change process, namely, the Management Committee (Manco), Deans and Directors of the administrative departments. The population comprised of 68 employees. The sample of 48 subjects was drawn using a stratified random sampling technique to ensure representation from the strata of the designated groups of interest. The three strata included Manco, Deans and Directors of the Administrative Departments (Finance, Personnel, Student Affairs, Buying and Stores Division and Research Administration). These groups of individuals are staff employed at three universities in the KwaZulu-Natal region, namely, University of Durban-Westville, University of Natal (Durban and Pietermaritzburg campuses) and the University of Zululand. The probability sampling technique was used to ensure representativity and enable the generalisability of results within the boundaries of the study. The response rate of $71 \%$ was achieved.

\section{Measurement}

In the absence of an established questionnaire on change management in an educational tertiary environment, a selfdeveloped questionnaire served as the basis of data collection. The structured questionnaire consisted of Section A : biographic information, and Section B comprising of items relating to the change process. In Section B, question one, respondents were asked to rate items on a 5-point itemised rating scale ranging from poor (1), not very well (2), fair (3), well (4) to very well (5). In the rest of Section B, respondents were required to rate items on a 5-point Likert scale ranging from strongly disagree (1), disagree (2), neither agree/not disagree (3), agree (4) to strongly agree (5). This format further enhanced the comparability of responses to all questions. The neutral choice in the middle of the scale was used to identify respondents with no opinion or those who chose not to make a choice. No incidents of a respondent constantly choosing the neutral position were found. Hence, the data was then used for further analysis. The questionnaire was formulated on the basis of identifying recurring themes that surfaced during the literature review and items included in the questionnaire related directly to the constructs being measured. This ensured face, content and construct validity. The items in the questionnaire clustered together to evaluate:

- The perceptions of the Management Committee, Deans and Directors regarding the manner in which the change process was communicated. The effectiveness of the process of communication and communication channels used were evaluated.

- Executive Management's perception of staff behaviour, feelings and knowledge (overall attitude comprising of the triad of the cognitive, affective and conative components) during the change process. The attitude of staff were evaluated on the basis of their level of understanding of the change process (cognitive component of attitudes), their feelings in terms of resistance to change, their levels of insecurity and commitment (affective component) and response to changes taking place (conative/action component).

- Executive Management's perception of their own knowledge and understanding of the change process. This was evaluated in terms of their understanding of policies and rationale for change.

- Executive Management's perception of the level of participation of staff in the change process. This was evaluated in terms of their perception of the extent to which staff was allowed to participate and contribute to the change process.

- Executive Management's perception of the management of, and impact of, the change process. This was assessed in terms of their perceptions of the impact of the new situation in providing challenges, satisfaction, incentives, opportunities for personal development and progress.
Administration of the measuring instrument

The questionnaires were personally administered to the subjects over a period of two months. First subjects were telephonically informed about the nature, purpose of, and rationale for, the study and personally requested to participate in the study. Once approval was obtained, the measuring instrument was delivered either to the subject or the secretary in a sealed envelope. Subjects were given a week to allow the sufficient time for the subject to introspect and think about each item. Questionnaires were returned using the internal mailing system to ensure anonymity or a self-addressed stamped envelope.

\section{Analysis}

Descriptive statistics (means, standard deviations) were used to analyse the quantitative data. The perceptions of employees of the change process were rated using itemised rating which ranged from poor (1) to very well (5). The key variables included communication, behaviour, feelings, knowledge, participation, management, and overall attitude; and respondents were requested to indicate their responses, using the 5 point Likert scale. Perceptions of executive management (Manco, Deans, Directors) regarding these variables were assessed using inferential statistics. The statistics used included analysis of variance (ANOVA) and chi-square correlation. The data from the questionnaires were captured using Excel (Version 5) and processed with the use of Simstat.

\section{RESULTS}

\section{Descriptive statistics}

The perceived impact of the variables of the study (communication, behaviour of employees, feelings and knowledge, participation) on the change management process (Figure 1).

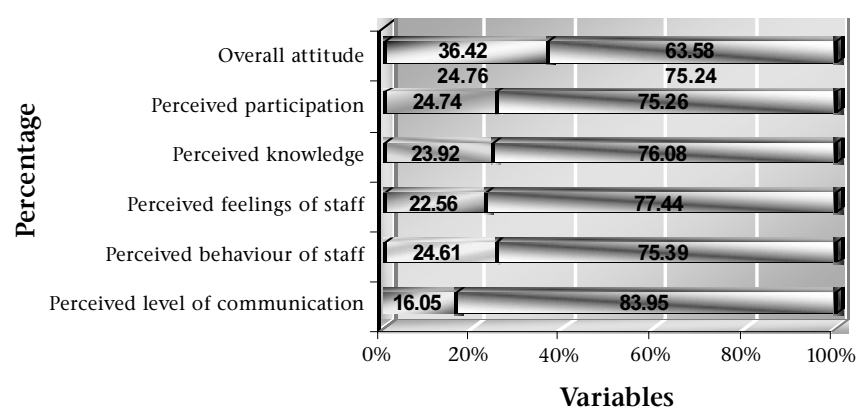

Figure 1: Impact of the variables on the change management process and the degree of improvement needed

The results of the study, depicted in Figure 1, indicate that the perceived impact of the variables of the study on the change process, in descending level of impact (based on mean score values) are:

- Perceived extent of participation in the change process 22,28 out of a maximum of $90(24,76 \%)$

- Perceived behaviour of staff in the change process $-24,61$ out of a maximum of $100(24,61 \%)$

- Perceived knowledge of management and staff $-23,92$ out of a maximum of $100(23,92 \%)$

- Perceived feelings of staff $-42,86$ out of a maximum of 190 $(22,56 \%)$

- Perceived level of communication during the change process $-6,42$ out of a maximum of $40(16,05 \%)$

- With regard to the overall attitude, the mean score was 142,3 out of a maximum of $390(36,42 \%)$.

For each variable, the segment on the right of the bar signifies the degree of improvement needed. There is a definite need for improvement in communication, which has a significantly low score. Of grave concern is that whilst participation has the 
highest mean, the overall average is far too low. The implication is that even the level of participation of staff during the change process was perceived to be unsatisfactory. Other areas that could be improved are feelings and knowledge.

Understanding of Executive Management of the policies and rationale for change

TABLE 1

EXeCUTIVE MANAgEMENT'S UNDERSTANDING OF POLICIES AND RATIONALE FOR CHANGE

\begin{tabular}{lcccc}
\hline Variable & Manco (8) & Deans(8) & Directors(8) & $\begin{array}{c}\text { Overall } \\
\text { Average (8) }\end{array}$ \\
\hline $\begin{array}{l}\text { Understanding of } \\
\text { policies }\end{array}$ & 4,00 & 3,67 & 4,20 & 3,96 \\
$\begin{array}{l}\text { Understanding } \\
\text { rationale for change }\end{array}$ & 4,33 & 3,80 & 4,07 & 4,07 \\
\hline
\end{tabular}

The results in Table 1 indicate that the level of understanding of Manco, Deans and Directors of the policies and rationale for change, in descending level (based on mean scores), was as follows:

- Directors reflected the highest level of understanding (Mean $=4,20)$ of policies, followed by Manco (Mean $=4,00)$, then Deans $($ Mean $=3,67)$.

- With regards to the rationale for change, Manco displayed the highest degree of understanding (Mean $=4,33$ ), followed by Directors at 4,07, and Deans at 3,80.

The low mean scores, obtained for the level of understanding of the change process, is reflected by Deans, for both issues relating to policies and rationale for change.

Perception of the changed process in providing challenges, satisfaction, incentives, personal development and progress

TABLE 2

EXECUTIVE MANAGEMENT'S PERCEPTION OF THE NEW SITUATION IN PROVIDING CHALLENGES, SATISFACTION, INCENTIVES, PERSONAL DEVELOPMENT AND PROGRESS

\begin{tabular}{lcccc}
\hline Variable & Manco (8) & Deans(8) & Directors(8) & $\begin{array}{c}\text { Overall } \\
\text { Average (8) }\end{array}$ \\
\hline Providing challenges & 4,42 & 4,40 & 4,33 & 4,38 \\
Providing satisfaction & 4,17 & 3,60 & 3,80 & 3,86 \\
Providing Incentives & 3,67 & 3,53 & 3,07 & 3,42 \\
$\begin{array}{l}\text { Providing Opportunities } \\
\text { for personal development }\end{array}$ & 4,17 & 3,93 & 3,60 & 3,90 \\
Resulting in progress & 4,17 & 4,00 & 3,27 & 3,81 \\
\hline
\end{tabular}

When comparing the new situation with the present one in terms of challenges, satisfaction, incentives, personal development and progress, the following results (as depicted in Table 2) were obtained:

- With regard to the new situation providing challenges, Manco reflected the highest score (Mean $=4,42$ ), followed by Deans $($ Mean $=4,40)$, and then Directors $($ Mean $=4,33$ ). The overall average is 4,38 .

- With regard to the new situation providing satisfaction, Manco reflected the highest score (Mean $=4,17)$, followed by Directors (Mean $=3,80)$, and Deans $($ Mean $=3,60)$. The overall average is 3,86 .

- With regard to the new situation providing incentives, Manco reflected the highest score (Mean $=3,67$ ), followed by Deans (Mean $=3,53)$, and Directors (Mean $=3,07)$. The overall average is 3,42 .
- With regard to the new situation providing opportunities for personal development, Manco reflected the highest score (Mean $=4,17)$, followed by Deans $($ Mean $=3,93)$, and Directors (Mean $=3,60$ ). The overall average is 3,9 .

- With regard to the new situation resulting in progress, Manco reflected the highest score of (Mean $=4,17)$, followed by Deans (Mean $=4,00$ ), and Directors (Mean $=3,27$ ). The overall average is 3,81 .

It is evident that Manco has the most positive perception of the changed situation (the process of transformation) in providing challenges, satisfaction, incentives, personal development and progress). On the whole, the Executive Management believes that the new situation, in descending level of overall average scores, has the greatest opportunity to provide challenges, personal development to staff, satisfaction to employees, opportunities for progress, and lastly, incentives to staff.

\section{Threat of changes to stakeholders}

Manco's perception of the current changes being a threat to Manco, staff and students were analysed using mean scores. Manco perceives that the current changes poses the greatest threat to staff (Mean $=3,67$ ), and then to students (Mean $=2,50)$ and least to themselves (Mean $=1,67$ ). There is a significant mean difference in current changes being a threat to Manco and staff. Whilst staff is perceived as viewing the changes as a threat (Mean $=3,67$ ), Manco does not see the changes as being a serious threat $($ Mean $=1,67)$.

Perceived impact of the changed situation on efficiency and effectiveness

The impact of the new situation to efficiency and effectiveness in the short-term and long-term as perceived by Manco and Directors were reflected as follows:

- In the short-term, Directors perceived the new situation as having more of a negative impact on efficiency and effectiveness (Mean $=3,67$ ) as compared to Manco (Mean = $3,08)$.

- The perceptions of Manco and Directors regarding the impact of the new situation on efficiency and effectiveness are reversed in the longer term.

\section{Inferential statistics}

Communication and Knowledge across the institutions of learning (University of Zululand, University of Natal, University of Durban-Westville).

The perceptions of the Executive Management (Manco and Directors, Deans and Manco, and Directors and Deans) regarding the impact of the variables of communication, behaviour, feelings, knowledge, participation, management and overall attitude on change management respectively were correlated.

The perceptions of Manco and Directors regarding the impact of the variables on the change management process were correlated (Table 3).

From Table 3, the following were noted:

- Manco's perceptions of communication shows a significant, but inverse correlation with Directors' behaviour $(r=-0,631$; $p=0,028)$. Manco's knowledge of the change process correlates significantly, though inversely with Directors' participation in the change process $(r=-0,576 ; p=0,05)$. Manco's participation in the change process correlates significantly, but inversely, with Directors' behaviour $(\mathrm{r}=$ $-0,666 ; p=0,018)$. The inverse relationships emphasize the call for concern. No other relationships show significance.

The perceptions of Manco and Deans regarding the impact of the variables on the change management process were correlated (Table 3). From Table 3, the following were evident: 
TABLE 3

Intercorrelation: Perceptions of executive management (Manco and Directors, Manco and Deans) Regarding THE IMPACT OF THE VARIABLES ON CHANGE MANAGEMENT RESPECTIVELY $\left({ }^{*} \mathbf{P} \leq \mathbf{0 , 0 5}\right)$

\begin{tabular}{|c|c|c|c|c|c|c|c|c|}
\hline Variable & & $\begin{array}{c}\text { Manco } \\
\text { Communication }\end{array}$ & $\begin{array}{c}\text { Manco } \\
\text { Behaviour }\end{array}$ & $\begin{array}{l}\text { Manco } \\
\text { Feelings }\end{array}$ & $\begin{array}{c}\text { Manco } \\
\text { Knowledge }\end{array}$ & $\begin{array}{c}\text { Manco } \\
\text { Participation }\end{array}$ & $\begin{array}{c}\text { Manco } \\
\text { Management }\end{array}$ & $\begin{array}{c}\text { Manco } \\
\text { Overall attitude }\end{array}$ \\
\hline Directors & $\mathrm{r}$ & $-0,563$ & $-0,354$ & 0,088 & 0,381 & 0,257 & Directors were not & 0,151 \\
\hline Communication & $\mathrm{p}$ & 0,057 & 0,260 & 0,785 & 0,222 & 0,420 & assessed on executive & 0,639 \\
\hline Directors & $\mathrm{r}$ & $-0,631$ & 0,196 & 0,356 & $-0,407$ & $-0,666$ & management issues & $-0,484$ \\
\hline Behaviour & $\mathrm{p}$ & $0,028 *$ & 0,542 & 0,256 & 0,189 & 0,018 * & & 0,111 \\
\hline Directors & $\mathrm{r}$ & $-0,043$ & $-0,246$ & 0,428 & $-0,192$ & 0,139 & & $-0,131$ \\
\hline Feelings & $\mathrm{p}$ & 0,893 & 0,441 & 0,166 & 0,551 & 0,667 & & 0,685 \\
\hline Directors & $\mathrm{r}$ & $-0,004$ & 0,311 & $-0,165$ & 0,164 & $-0,224$ & & 0,112 \\
\hline Knowledge & $\mathrm{p}$ & 0,991 & 0,326 & 0,609 & 0,611 & 0,485 & & 0,729 \\
\hline Directors & $\mathrm{r}$ & $-0,265$ & 0,050 & 0,125 & $-0,576$ & $-0,018$ & & $-0,291$ \\
\hline Participation & $\mathrm{p}$ & 0,404 & 0,878 & 0,698 & 0,050 * & 0,955 & & 0,359 \\
\hline Directors & $\mathrm{r}$ & $-0,197$ & 0,015 & 0,492 & $-0,222$ & $-0,232$ & & $-0,263$ \\
\hline Overall attitude & $\mathrm{p}$ & 0,540 & 0,964 & 0,104 & 0,488 & 0,468 & & 0,409 \\
\hline Deans & $\mathrm{r}$ & 0,257 & 0,592 & $-0,316$ & 0,432 & $-0,322$ & $-0,092$ & 0,224 \\
\hline Communication & $\mathrm{p}$ & 0,419 & $0,043^{*}$ & 0,316 & 0,161 & 0,307 & 0,776 & 0,484 \\
\hline Deans & $\mathrm{r}$ & 0,130 & $-0,423$ & 0,369 & $-0,187$ & 0,314 & 0,062 & 0,005 \\
\hline Behaviour & $\mathrm{p}$ & 0,688 & 0,170 & 0,238 & 0,560 & 0,321 & 0,849 & 0,986 \\
\hline Deans & $\mathrm{r}$ & $-0,079$ & 0,347 & $-0,439$ & 0,356 & $-0,306$ & $-0,142$ & $-0,159$ \\
\hline Feelings & $\mathrm{p}$ & 0,807 & 0,270 & 0,154 & 0,255 & 0,333 & 0,660 & 0,621 \\
\hline Deans & $\mathrm{r}$ & 0,533 & $-0,025$ & 0,022 & 0,713 & $-0,332$ & $-0,059$ & 0,181 \\
\hline Knowledge & $\mathrm{p}$ & 0,074 & 0,938 & 0,947 & $0,009 *$ & 0,292 & 0,856 & 0,575 \\
\hline Deans & $\mathrm{r}$ & 0,193 & 0,621 & $-0,543$ & 0,453 & $-0,267$ & $-0,368$ & 0,142 \\
\hline Participation & $\mathrm{p}$ & 0,547 & 0,031 * & 0,068 & 0,140 & 0,402 & 0,239 & 0,659 \\
\hline Deans & $\mathrm{r}$ & 0,378 & 0,072 & $-0,069$ & 0,699 & 0,098 & $-0,072$ & 0,310 \\
\hline Management & $\mathrm{p}$ & 0,225 & 0,824 & 0,832 & 0,011 * & 0,761 & 0,825 & 0,327 \\
\hline Deans & $\mathrm{r}$ & 0,388 & 0,452 & $-0,312$ & 0,886 & $-0,051$ & $-0,188$ & 0,448 \\
\hline Overall attitude & $\mathrm{p}$ & 0,212 & 0,140 & 0,323 & $0,000^{*}$ & 0,875 & 0,558 & 0,144 \\
\hline
\end{tabular}

TABLE 4

Intercorrelation: Perceptions of management (Deans AND Directors) Regarding the impact of THE VARIABLES ON CHANGE MANAGEMENT RESPECTIVELY

\begin{tabular}{|c|c|c|c|c|c|c|c|}
\hline Variable & & $\begin{array}{c}\text { Deans } \\
\text { Communication }\end{array}$ & $\begin{array}{c}\text { Deans } \\
\text { Behaviour }\end{array}$ & $\begin{array}{l}\text { Deans } \\
\text { Feelings }\end{array}$ & $\begin{array}{c}\text { Deans } \\
\text { Knowledge }\end{array}$ & $\begin{array}{c}\text { Deans } \\
\text { Participation }\end{array}$ & $\begin{array}{c}\text { Deans } \\
\text { Overall attitude }\end{array}$ \\
\hline Directors & $\mathrm{r}$ & 0,741 & $-0,310$ & $-0,182$ & $-0,167$ & $-0,515$ & $-0,196$ \\
\hline Communication & $\mathrm{p}$ & 0,002 * & 0,261 & 0,517 & 0,552 & 0,050 * & 0,484 \\
\hline Directors & $\mathrm{r}$ & 0,219 & $-0,284$ & 0,277 & 0,000 & 0,252 & 0,170 \\
\hline Behaviour & $\mathrm{p}$ & 0,433 & 0,304 & 0,317 & 1,000 & 0,365 & 0,544 \\
\hline Directors & $\mathrm{r}$ & $-0,214$ & 0,260 & 0,052 & 0,326 & 0,123 & 0,361 \\
\hline Feelings & $\mathrm{p}$ & 0,444 & 0,350 & 0,855 & 0,235 & 0,663 & 0,186 \\
\hline Directors & $\mathrm{r}$ & $-0,024$ & $-0,414$ & 0,113 & 0,415 & $-0,036$ & $-0,154$ \\
\hline Knowledge & $\mathrm{p}$ & 0,932 & 0,125 & 0,689 & 0,124 & 0,898 & 0,583 \\
\hline Directors & $\mathrm{r}$ & $-0,600$ & 0,152 & $-0,434$ & 0,246 & 0,080 & $-0,426$ \\
\hline Particpation & $\mathrm{p}$ & $0,018^{*}$ & 0,589 & 0,106 & 0,376 & 0,777 & 0,114 \\
\hline Directors & $\mathrm{r}$ & $-0,004$ & $-0,232$ & $-0,536$ & 0,308 & 0,041 & $-0,371$ \\
\hline Overall attitude & $\mathrm{p}$ & 0,989 & 0,405 & 0,040 * & 0,263 & 0,884 & 0,173 \\
\hline
\end{tabular}

${ }^{*} \mathrm{p} \leq 0,05$

- Manco's perceptions of behaviour correlates significantly with Deans' communication ( $r=0,592 ; \mathrm{p}=0,043)$ and with Deans' perceptions of participation $(r=0,621 ; p=0,031)$.

- Manco's knowledge correlates significantly with Manco's knowledge $(r=0,713 ; p=0,009)$, and Manco's knowledge correlates significantly with Deans' management of change $(\mathrm{r}=0,699 ; \mathrm{p}=0,011)$, and Deans' overall attitude $(\mathrm{r}=0,886$; $\mathrm{p}=0,000)$, respectively. No other relationships show significance.

The perceptions of Deans and Directors regarding the impact of the variables on the change management process were correlated (Table 4).

From Table 4, the following were evident:

- Deans' perceptions of communication correlates significantly with Director's perceptions of communication $(\mathrm{r}=0,741 ; \mathrm{p}=0,002)$ of the change process. Deans' communication correlates significantly, but inversely with the Director's perception of participation $(r=-0,600 ; p=$ $0,018)$, Deans' feelings correlates significantly, though inversely, with the Director's overall attitude $(r=-0,536$; $p=$ 0,040 ), and Deans' participation correlates significantly, but inversely, with the Director's communication $(r=-0,515 ; \mathrm{p}$ $=0,050)$. It is clear that Directors and Deans' view communication and participation in the change process differently. They also reflect differing feelings and overall attitudes to the change process. No other relationships show significance.

Perceived impact of changed situation on efficiency and effectiveness

The results indicate that there is no significant correlation between the perceptions of Manco and Directors regarding the 
impact of the new situation on their effectiveness and efficiency in the short and long terms (Table 5).

TABLE 5

CHI-SQUARE STATISTIC: IMPACT OF CHANGE ON EFFECTIVENESS AND EFFICIENCY

\begin{tabular}{lccc}
\hline Variable & Value & df & $\mathbf{p}$ \\
\hline $\begin{array}{l}\text { Impact of new situation on effectiveness } \\
\text { and efficiency: short-term }\end{array}$ & 11,998 & 12 & 0,446 \\
$\begin{array}{l}\text { Impact of new situation on effectiveness } \\
\text { and efficiency: long-term }\end{array}$ & 12,540 & 12 & 0,403 \\
\hline
\end{tabular}

The results in Table 5 confirm that hypothesis 5 may be refuted at the $5 \%$ level of significance.

Perceived acceptance and understanding of the change process

The results of the study reflect that there is no significant correlation between the perceptions of the Deans regarding how the change process was accepted and understood by staff and students respectively (Table 6).

TABLE 6

CHI-SQUARE STATISTIC: DEAN'S PERCEPTION OF STAFF AND STUDENTS' ACCEPTANCE AND UNDERSTANDING OF THE CHANGE PROCESS

\begin{tabular}{lccc}
\hline Variable & Value & df & p \\
\hline $\begin{array}{l}\text { Perceived acceptance and understanding of } \\
\text { change process by staff }\end{array}$ & 1,632 & 1 & 0,201 \\
$\begin{array}{l}\text { Perceived acceptance and understanding } \\
\text { of change process by students }\end{array}$ & 4,463 & 4 & 0,347 \\
\hline
\end{tabular}

The results in Table 6 reflect that hypothesis 6 may be rejected at the $5 \%$ level of significance.

The results of the study are graphically presented in Figure 2 .

\section{DISCUSSION OF RESULTS}

The results indicate that communication in the change process was perceived in the most negative light. This is of grave concern since effective communication is considered to be the critical element in effectively managing change. Errors made due to managers' behaviour being inappropriate such as "under-communication, lack of goal-setting, and poor team-management skills", can lead to "negative outcomes", meaning that change agents can change both their "own - and organizational - performance if they change their own behaviour" (Seijts \& O'Farrell, 2003: 2). This is particularly important as the results of this study indicate that insufficient cognisance was given to staff feelings, knowledge of the change process and behaviour. Whilst participation had the highest mean, there was still tremendous room for improvement. With the convergence of universities and rightsizing initiatives, staff feel threatened, uncertain and disempowered. Therefore, staff need to feel consulted and involved in processes. According to Tam (1999), it is not structures alone that will create a sense of cohesion but with vision, goal setting and motivation, modifications to staff behaviour can occur. An initial step is for the leader to pave the way for the change and to create an environment of teamwork, cooperation and purpose. Clearly, the results indicate that staff attitude (comprising of the triad of feelings, knowledge and behaviour) to the change process needs to be taken seriously, especially because feelings of staff can have a tremendous influence on the change process as a whole.

Although standardized procedures and equity concerns are, inter alia, standard features of a higher educational system, the effectiveness of tertiary educational institutions are attributed to the contribution and dedication of all staff. In South Africa, the merger and rightsizing initiatives have affected tertiary staff. Seijts \& O'Farrell (2003) assert that only recently have managers begun to consider the emotional content and impact of a message in communicating organisational change. Change is essentially about feelings and if companies need workers to contribute with their heads and hearts, they have to accept that emotions are an essential aspect to the new management style and how to deal with them is critical (Seijts \& O'Farrell, 2003).

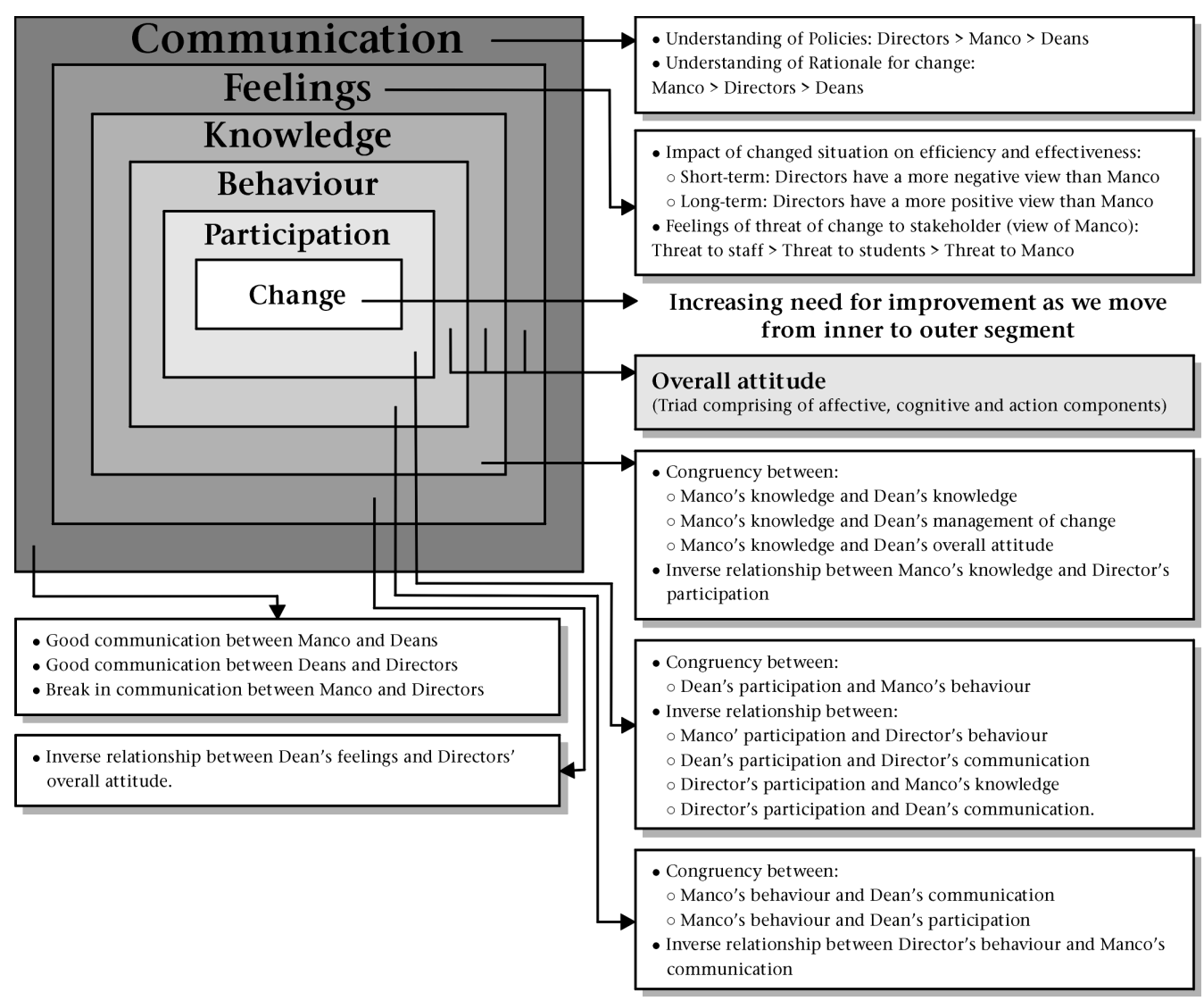

Figure 2: Results of the study 
The following results of the study raise several aspects of concern which is indicative of poor change management:

- An unacceptable level of understanding of policies and rationale for change, especially reflected by Deans.

- A poor impression of the impact of the changed situation on challenges, satisfaction, incentives, personal development and progress, especially reflected by Directors.

- Staff view the change as a threat.

- Perceived negative impact of the change process in the short term, reflected by Directors.

- The inverse correlations between communication and behaviour, knowledge and participation, participation and behaviour and communication and feelings imply incongruence in the system.

The aforementioned results clearly reflect an inadequate level of communication and the unsuitable nature of communication from the Executive to the various levels of staff. If Deans and Directors, who have a close link with the Executive Management, are uncertain about the policies, rationale for change, process and impact of the change process, then staff insecurity, under-communication, lack of goalsetting and poor team-management skills are obvious negative outcomes. Whilst Manco reflected the most positive perception of the change process and believed that the process had the potential to provide greater challenges, satisfaction, incentives, personal development and progress, this was evidently not effectively communicated to staff, who sees the change process as a threat.

Furthermore, meeting the challenges of the change process demands the highest calibre of leaders and managers who are prepared and able to embrace change through developing management practices and raising the level of strategic thinking within their institutions (Newby, 2003). The results indicate that there is a need for individuals, especially Deans and Directors, to possess greater and improved skills in order to manage the process of change. They need to play their role more enthusiastically and have a better understanding of their responsibilities. The Directors and Deans cannot be held accountable as it is clearly evident that the Executive did not invest further or sufficiently in the professional development of managers and leaders at all levels within the institutions to equip them to understand and effectively manage the change process. In addition, it is evident that insufficient attention was given to the 'people' aspect and the feelings of the staff. Price (1994: 37) asserts that "the effective operation of a university depends on the willing assent of the staff to work within whatever structure is prescribed. All your mistakes will be people mistakes; and your successes will be people successes". The creation of an "informal atmosphere of teamwork, co-operation and purpose is immensely more important than the formal structural framework within which it purports to take place" (Price, 1994: 42). Clearly the new management paradigm of managing people through managing feelings was not adopted. The results indicate that difficulties in the change process can be attributed to:

- poor and insufficient communication about, and knowledge on how to manage, the change process.

- the lack of strong leadership to provide new direction, to motivate people to change their behaviours and activities consistent with the new direction and to coach them on how to overcome obstacles to change.

\section{Recommendations}

Evidently, the communication factor has emerged many times. Hence, tertiary educational change managers need to act responsibly by conveying messages effectively so that staff understand and accept the process of change. Such information must relate the factual message and latest developments at tertiary educational institutions. In this way, staff attitude to change can be nurtured in a positive light.

Staff is definitely perceived as viewing the change process as a threat. A natural reaction to feelings of uncertainty is to resist

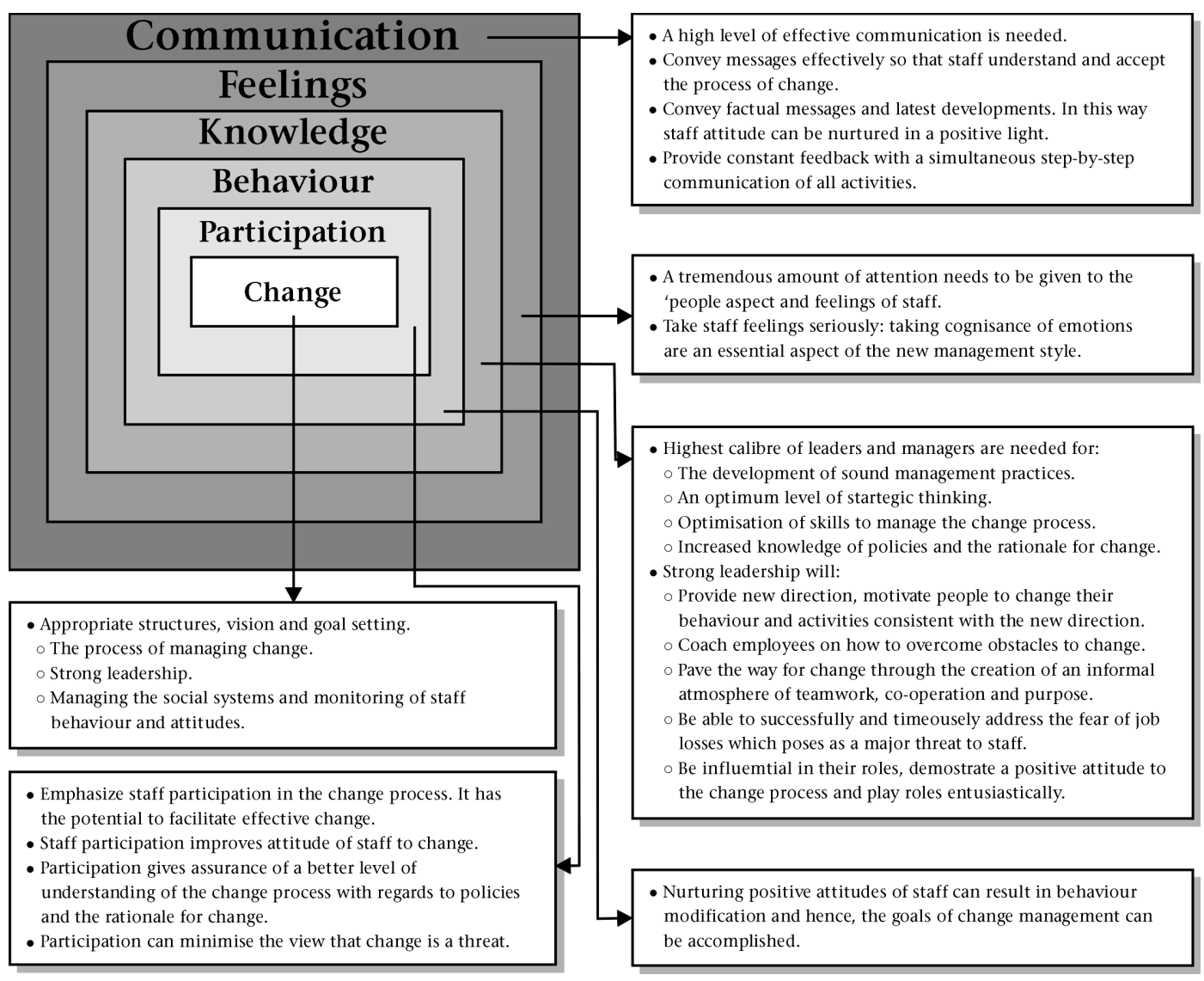

Figure 3: Recommendations for Effective Change Management 


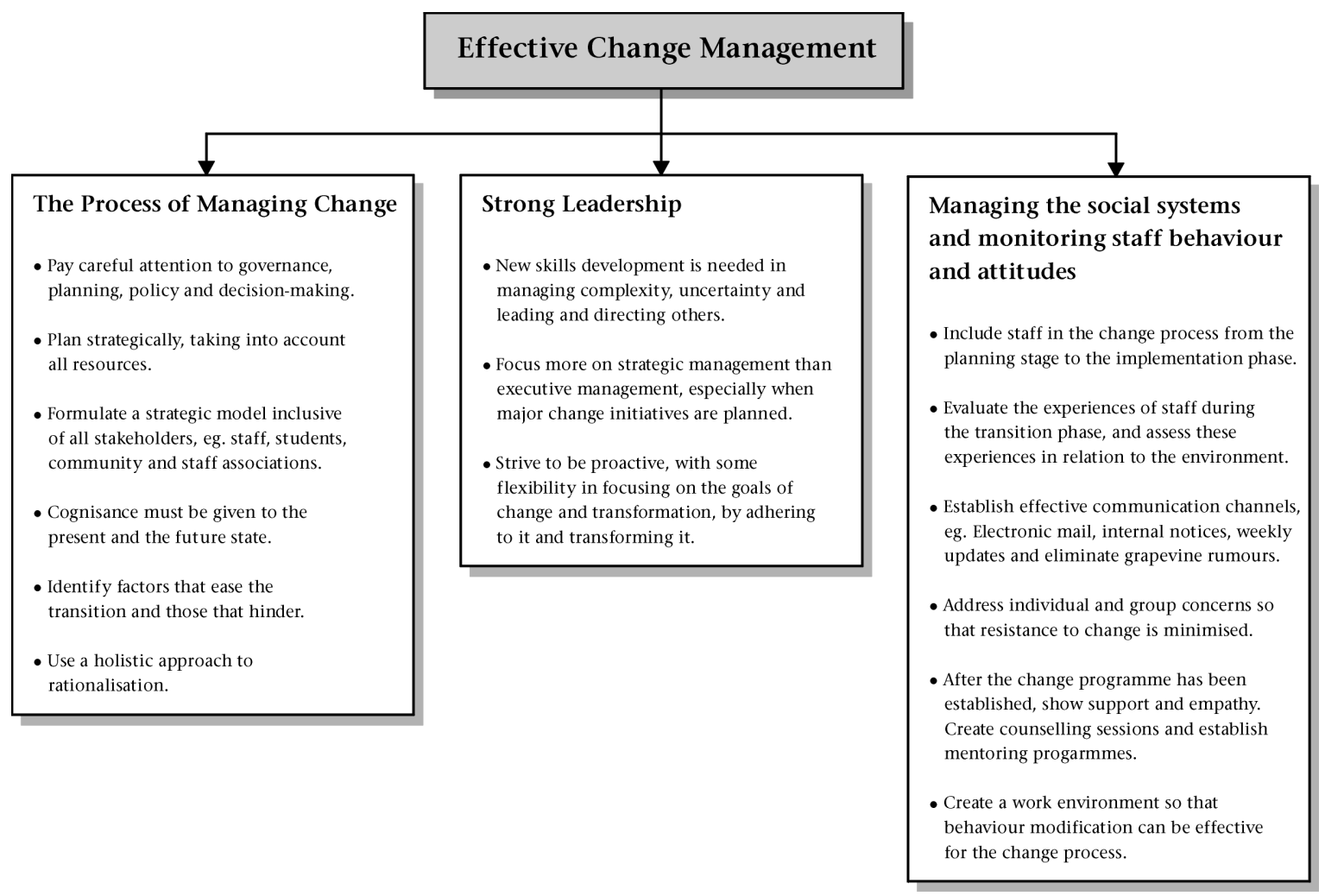

Figure 4: Critical recommendations - managing the change process and the need for strong leadership

change. Staff are affected by changes, based on their perceptions, feelings, behaviour, knowledge and hence, attitude. With the rationalisation and merger initiatives at tertiary educational institutions, staff is uncertain, feel threatened and insecure about their future. Hence, it is recommended that during the change process, constant feedback be given to staff, with a simultaneous step-by-step communication of all activities. Tertiary change managers need to be more attentive towards the attitude of staff. Since the attitudes of staff are influenced by people and situations, improvement in these areas can change the overall attitude of staff toward the current changes. In addition, due consideration and emphasis should be placed on staff participation in the change process due to its potential to facilitate effective change (Figure 2).

Recommendations based on the results of the study aimed at improving communication, the management of staff attitude and behaviour and staff participation during the change management process are presented in Figure 3.

\section{Conclusion}

Critical to effective change management is the process of managing change and the need for strong leadership. Furthermore, social systems need to be harnessed and staff attitude and behaviour need to be monitored. This requires the formulation of a strategic model, taking cognisance of all aspects of change. In this way, plans for new situations can be more decisive. Recommendations with regards to managing the change process, developing strong leadership and managing social systems in a change process are presented in Figure 4.

A significant conclusion is that tertiary educational change managers need to undertake the change management task with the commitment, dedication and support of all staff. For too long, change managers have focused on adopting logical, rational arguments to change the behaviour of individuals (Seijts \& O'Farrell, 2003). There is a need for a holistic approach to change management. Helping people to see or feel problems, solutions or progress will influence their emotions, which in turn, enhances their commitment to behavioural change or reinforces change behaviour (Seijts \& O'Farrell, 2003). Undoubtedly, the external factors, especially the national plan for tertiary educational institutions, government legislation and fluctuating markets, together with the internal systems and processes, reflect the enormity of the role and task of tertiary educational change managers.

With changes, higher education can establish itself on its strengths, creating the emergence of high powered tertiary educational institutions as a driving force to build dynamic institutions, which is certainly required for the twenty first century.

\section{REFERENCES}

Bowin, R.B. (2001). Human resource management: An experiential approach. Second Edition. New Jersey: Prentice-Hall.

Chang, R.Y. (1994). Mastering change management: A practical guide to turning obstacles into opportunities. USA: Richard Change Associates, Inc.

Dailey, R., Keenan, T. \& Tayeb, M.H. (1994). Organisational behaviour: A distance learning programme. Heriot-Watt Business School MBA Series. UK: Pitman Publishing.

Eisenbach, R., Watson, K. \& Pillai, R. (1999). Transformational leadership in the context of organizational change. Journal of Organizational Change Management, 12 (2), 80-88.

Fox, W., Schwella, E. \& Wissink, H. (1991). Public management. Kenwyn: Juta \& Company Limited.

Gibson, J.L., Ivancevich, J.M. \& Donnelly, J.R. (1994). Organisations. USA: Richard D. Irwin.

Green paper on higher education transformation. (1996). Department of Education. December. Pretoria, South Africa.

Hammond, V. (1999). Managing organizations in complex environments. Organizations \& people, The Quarterly Journal of AMED. 6 (2), 33-38. 
New directions for student services. (2000). The changing landscape of higher education, No. 2, Winter, Josey-Bass Publishers, 5-16.

Newby, H. (2003). The management of change in higher education. Higher Education Management and Policy, 15 (1), 9-22. HEPCE, United Kingdom.

Price, C. (1994). Piloting higher education change: a view from the helm in Web, S. (Ed.) Introducing 'Change From the Top' in Universities and Colleges. London, Kogan Page.

Seijts, G.H. \& O'Farrell, G. (2003). Engage the heart: Appealing to the emotions facilitates change. Ivey Business Journal, January/February 2003, 1-5.
Tam, M. (1999). Managing change involves changing management: implications for transforming higher education. Quality in Higher Education, 5 (3).

Van der Waldt, G. \& Knipe, A. (1998). Project management: For strategic change and upliftment. Johannesburg: International Publishing (Southern Africa) Pty, Ltd.

Van Tonder, C.L. (2004). Organisational Change: Theory and practice. Pretoria: Van Schaik Publishers.

Varghese, N.V. (2004). Incentives and institutional changes in higher education. Higher Education Management and Policy, 16 (1), 27-39. 